\title{
Aegialiinae LAPORTE, 1840 (Coleoptera: Scarabaeidae) of Poland
}

\author{
ŁUKASZ MinkINA $^{1 *}$, CEZARY NOWAK ${ }^{2}$, BARTŁOMIEJ PACUK ${ }^{3}$, \\ DAWID MARCZAK ${ }^{4,5}$, TOMASZ RUTKOWSKI ${ }^{6}$, SZYMON KONWERSKI $^{6}$, \\ ANDRZEJ MATUSIAK ${ }^{7}$, ADAM BYK ${ }^{8}$ \\ ${ }^{1}$ Polana Szaflarska 4/39, 34-400 Nowy Targ, Poland \\ ${ }^{2}$ Południowa 14, 29-100 Włoszczowa, Poland \\ ${ }^{3}$ Al. Powstańców Wielkopolskich 21/4, 85-090 Bydgoszcz, Poland \\ ${ }^{4}$ Department of Engineering and Management, University of Ecology and Management in \\ Warsaw, Olszewska 12, 00-792 Warszawa, Poland \\ ${ }^{5}$ Kampinos National Park, Tetmajera 38, 05-080 Izabelin, Poland \\ ${ }^{6}$ Natural History Collections, Faculty of Biology, Adam Mickiewicz University, \\ Umultowska 89, 61-614 Poznań, Poland \\ ${ }^{7}$ Anielewicza 18a/50, 01-032 Warszawa, Poland \\ ${ }^{8}$ Department of Forest Protection and Ecology, Warsaw University of Life Sciences - \\ SGGW, Nowoursynowska 159/34, 02-776 Warszawa, Poland
}

\begin{abstract}
Data on the distribution of Aegialiinae in Poland are summarized, and some new records are added. Photographs of all the species occurring in Poland and an identification key to them are provided, along with some fresh aspects of their biology. The aedeagus and epipharynx of all species present in Poland are illustrated photographically for the first time.

KEY WORDS: Aegialiinae, Aegialia, Psammoporus, Rhysothorax, faunistics, morphology, Poland.
\end{abstract}

\footnotetext{
* Corresponding author: klekel@interia.eu
} 


\section{INTRODUCTION}

The first data on the Aegialiinae LAPORTE, 1840 occurring in Poland (within her presentday borders) and neighbouring countries were provided by ILLIGER (1798), who reported Aegialia arenaria (FABRICIUS, 1787) and Psammoporus sabuleti (PANZER, 1797) from Prussia. Later, DOMMER (1850) reported the occurrence of Rhysothorax rufus (FABRICIUS, 1792), also from Prussia. The first data relating to precise localities of Aegialiinae in Poland were published by ŁOMNICKI (1874): he reported Psammoporus sabuleti from Zakopane in the Tatra Mts. In 1886 he provided detailed information on P. sabuleti - two specimens had been collected in Zakopane and were subsequently deposited in the Dzieduszycki Museum in Lviv. HILDT (1896) published further data, listing localities of Aegialia arenaria and Rhysothorax rufus. Interestingly, as a result of synonymization, he treated Psammoporus sabuleti as a synonym of Aegialia arenaria, explaining the reasons for doing so in a later paper (HILDT, 1916). LOMNICKI (1913) gave four species of Aegialiinae in his checklist of the beetles of Poland: A. arenaria, Rhysothorax rufus, Psammoporus sabuleti and P. latipunctus (GREDLER, 1866). The last-named species was reported from Chornohora, which lies beyond the present-day borders of Poland. The country's present-day frontiers were established in 1945, and the list of species occurring within them was updated by STEBNICKA (1976). STEBNICKA (1977) subsequently added a lot of information about the distribution of Aegialiinae in Poland. PITTINO (2006) described Psammoporus mimicus as a new species most closely related to P. latipunctus, and reported it as a new species for Poland based on a single, old specimen from Cieszyn deposited in the Museum of Natural History in Vienna. Recently, RöSSNER (2012) summed up the data on Aegialiinae from eastern Germany, with a thorough analysis of their distribution, biology and ecological conditions.

The present paper summarizes all the available data on the distribution of Aegialiinae in Poland based on accessible literature containing original data (not citations) with localities that can be pinpointed. Where the nature of the data cannot be precisely stated, this is indicated in the comments on the species. Photographs of the aedeagus and epipharynx of all species with a brief diagnosis are published for the first time. The aedeagus of Psammoporus sabuleti and P. mimicus PITTINo, 2006 were illustrated in PITTINo (2006), but only with short comments; the aedeagus of Aegialia arenaria, and Rhysothorax rufus were illustrated in STEBNICKA (2011) but without comment. 


\section{MATERIALS AND METHODS}

Comments on the labels and places of deposit are added in square brackets. The photographs were taken with a Canon EOS 5D Mark III camera fitted with a Canon MP-E $65 \mathrm{~mm}$ macro lens and edited using Helicon Focus. The morphological terms used to describe the epipharyngeal structures follow Dellacasa et al. (2010). The following symbols are used on the maps: data inaccurate or very likely so - for specimens incorrectly reported, but subsequently correctly interpreted by their (or other) authors, and for specimens whose identifications were most likely incorrect and not questioned earlier by other authors (triangle); historical data - collected up to 1945 (white circle); specimens collected in between 1945 and 2000 (after the current borders of Poland were established) (partly black, partly white circle); specimens collected after the year 2000, i.e. current localities (black circle).

The localities were assigned to one of the geographical regions given in the Catalogue of the Polish Fauna (Katalog Fauny Polski - Burakowski et al. 1983), and to a UTM square wherever possible.

The following abbreviations are used: NMP - National Museum, Prague; ISEA Institute of Systematics and Evolution of Animals, Kraków; ZIP - Zoological Institute, St. Petersburg; MIZ - Museum and Institute of Zoology, Polish Academy of Sciences, Łomna; USMB - Upper Silesian Museum, Bytom; NMV - Museum of Natural History, Vienna; DFPE - Department of Forest Protection and Ecology, Warsaw University of Life Sciences; and the private collections of the following persons: AB - Adam BYK, AM Andrzej MatusiaK, BB - Bartłomiej BujniK, BP - Bartłomiej PACUK, CN - Cezary NOWAK, JS - Jiři STANOVSKÝ, KO - Kamil ORSZULIK, LK - Lubomir KOLONIČNÝ, ŁM Lukasz MINKINA, MB - Marek BYK, MK - Maciej KAŹMIERCZAK, RC - Rafał CIEŚLAK, RD - Roland Dobosz, RP - Rafał PIASKOwSKI, SK - Szymon KonwERSKI, TG - Tomasz GAZUREK, and TR - Tomasz RUTKOWSKI.

\section{RESULTS AND DISCUSSION}

\section{Species overview}

Aegialia arenaria (FABRICIUS, 1787)

(Figs 1, 5, 9, 13, 17)

\section{Supplementary description}

Aedeagus: stocky; parameres slightly shorter than phallobase, with a very distinctly downwardly directed, acute apex. Epipharynx: very distinctly transverse, distinctly rounded 

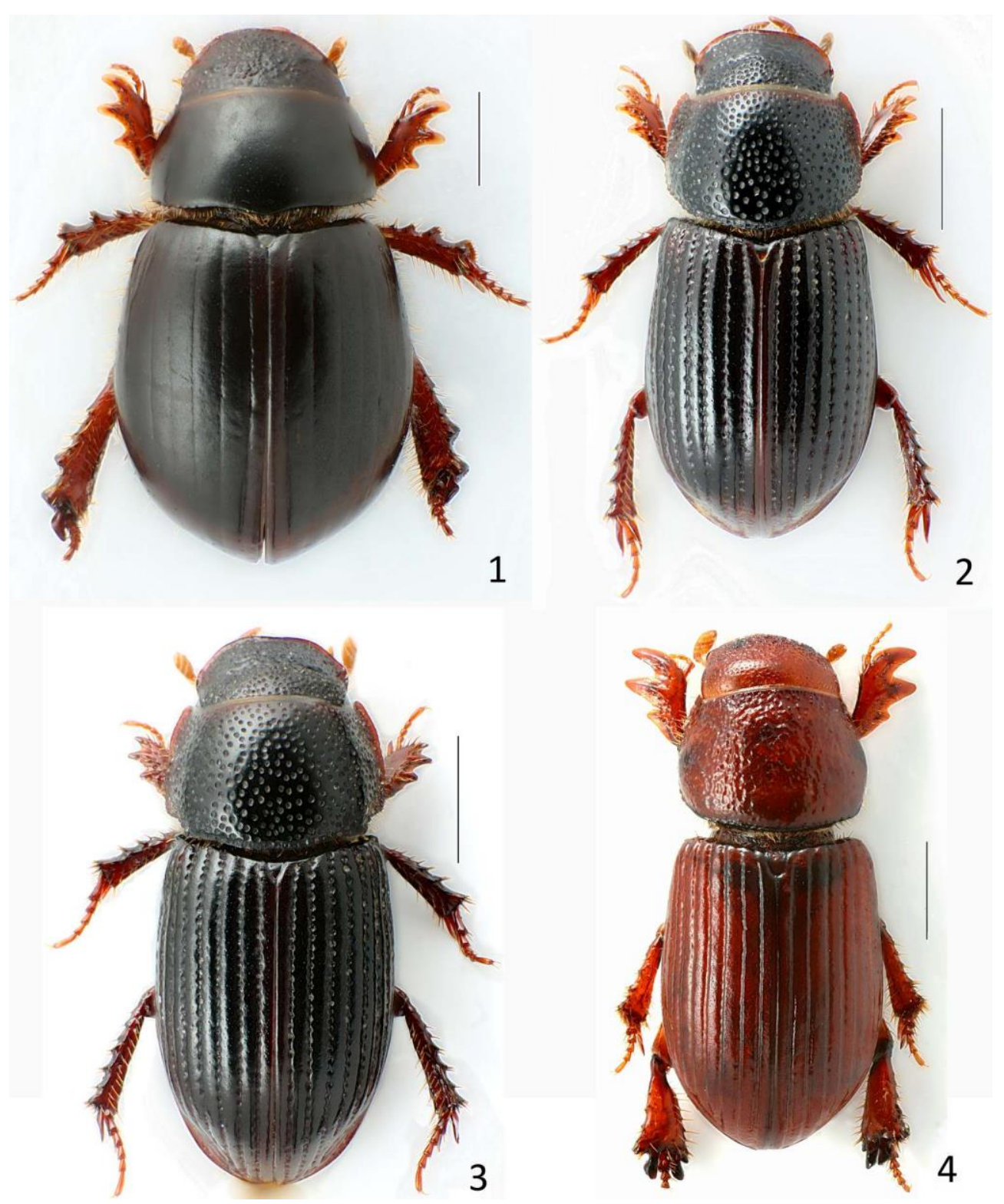

Figs 1-4. Imago: 1 - Aegialia arenaria (FABRICIUS, 1787), 2 - Psammoporus mimicus PITTINO, 2006, 3 - P. sabuleti (PANZER, 1797), 4 - Rhysothorax rufus (FABRICIUS, 1792). 


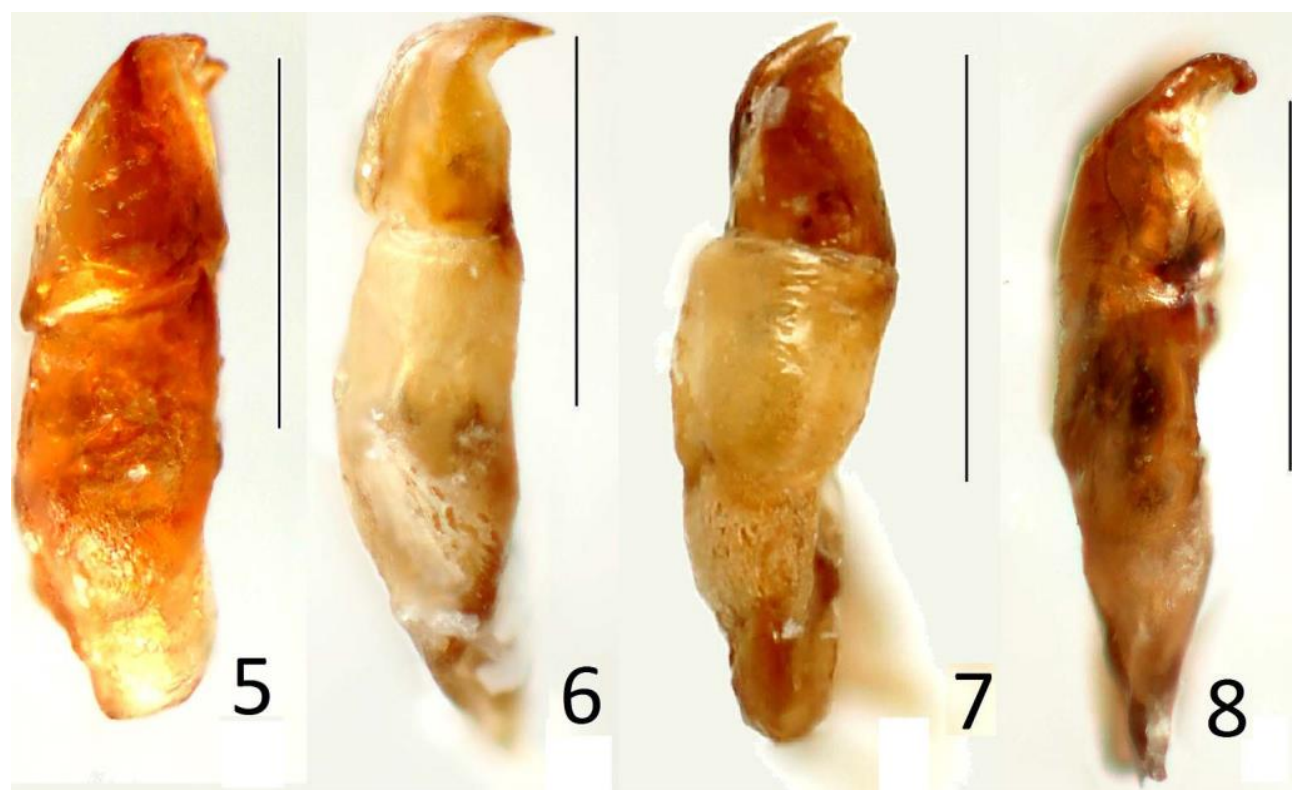

Figs 5-8. Aedeagus: 5 - Aegialia arenaria, 6 - Psammoporus mimicus, 7 - P. sabuleti, 8 - Rhysothorax rufus.

at sides, with anterior margin of pedia slightly concavely arcuate; corypha small, but distinctly visible, gently produced; chaetopariae almost indistinguishable from chaetopediae; tormae short, thick.

\section{Comment}

Stenotope, psammobiont, halophile. A common and widespread north European species introduced to Italy (Campania, Sardinia), North America and Japan. Found mainly on coastal beaches; single specimens very occasionally observed on extensive inland dunes. In Poland, recorded on Baltic Sea beaches, mainly on sand, in plant detritus, under stones, pieces of wood, and plant remains, occasionally in dung; lives mainly in the sand, between the roots of plants, sometimes quite deep. Observed from February to October, but mainly between May and August. Very probably with two generations per year; the imago is the overwintering stage; preimaginal stages unknown.

\section{New observations}

In Poland there are evidently two peaks of abundance: one from the end of May to the end of June, and the other from the end of August to the beginning of October. In our opinion this is because the species is bivoltine. 


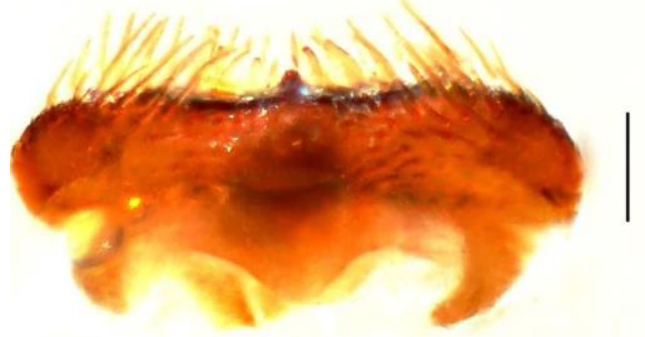

9

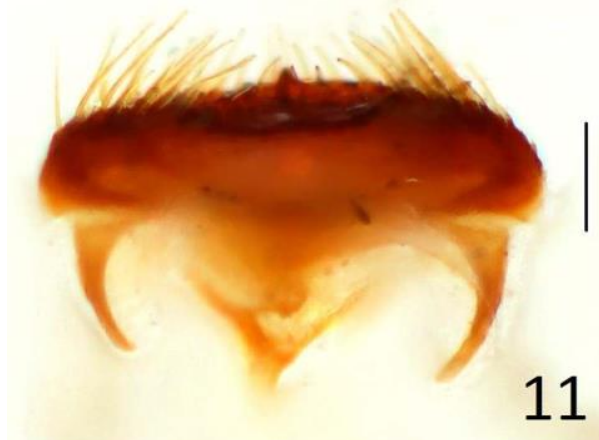

Figs 9-12. Epipharynx: 9 - Aegialia arenaria, $10-$ Psammoporus mimicus, $11-P$. sabuleti, 12 - Rhysothorax rufus.

\section{Literature data}

HILDT (1896): Mazovian Lowland: Miłosna near Warszawa [in fact Stara Miłosna, a district of Warszawa]; Małopolska Upland: vicinity of Busko [Zdrój]; Kraków-Wieluń Upland: vicinities of Olkusz and Ojców; Wielkopolska-Kujawy Lowland: vicinity of Ciechocinek; Nowy Targ Basin: Zakopane; SteBnICKA (1977): Baltic Coast: Koszalin, coll. KALLERT [NMP], coll. LÜLLWITZ [NMP, ISEA]; Szczecin [ZIP]; Gdańsk, 26.III.1922, coll. LGOCKI [ISEA]; Gdynia, 2.VIII.1931, leg. S. STOBIECKI [ISEA]; Hel pen., Jastarnia, 22.VII.1927, leg. S. STOBIECKI [ISEA], 1-15.VI.1972, leg. Z. STEBNICKA [ISEA]; Jurata, 115.VI.1972, on coastal dunes, leg. Z. STEBNICKA; CYKOWSKI (1979a): Baltic Coast: Słowiński National Park: a range of coastal dunes from Rowy to Łeba, 1977-1978, common; CYKOwsKI (1979b): Baltic Coast: Słowiński National Park: coastal strip in the vicinity of Wydmy Czołpińskie, VII.1975, VII.1976, the whole coastal strip in the vicinity of the Słowiński National Park, VII.1977, the most numerous at the foot of the dunes; AlEKSANDROwiCZ et al. (2004): Baltic Coast: Słowiński National Park (XA36, XA46, 

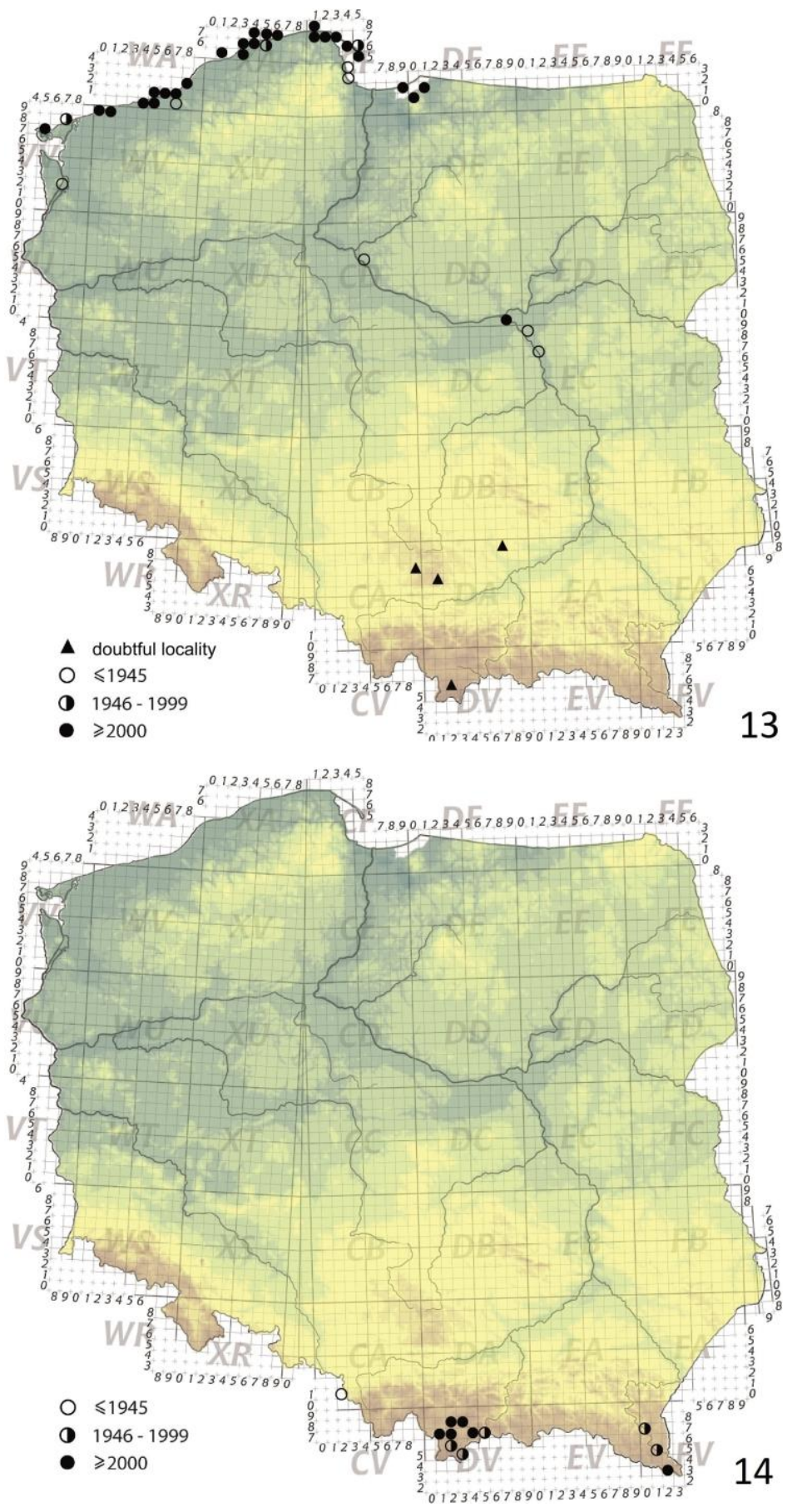

Figs 13, 14. Distribution maps: 13 - Aegialia arenaria, 14 - Psammoporus mimicus. 

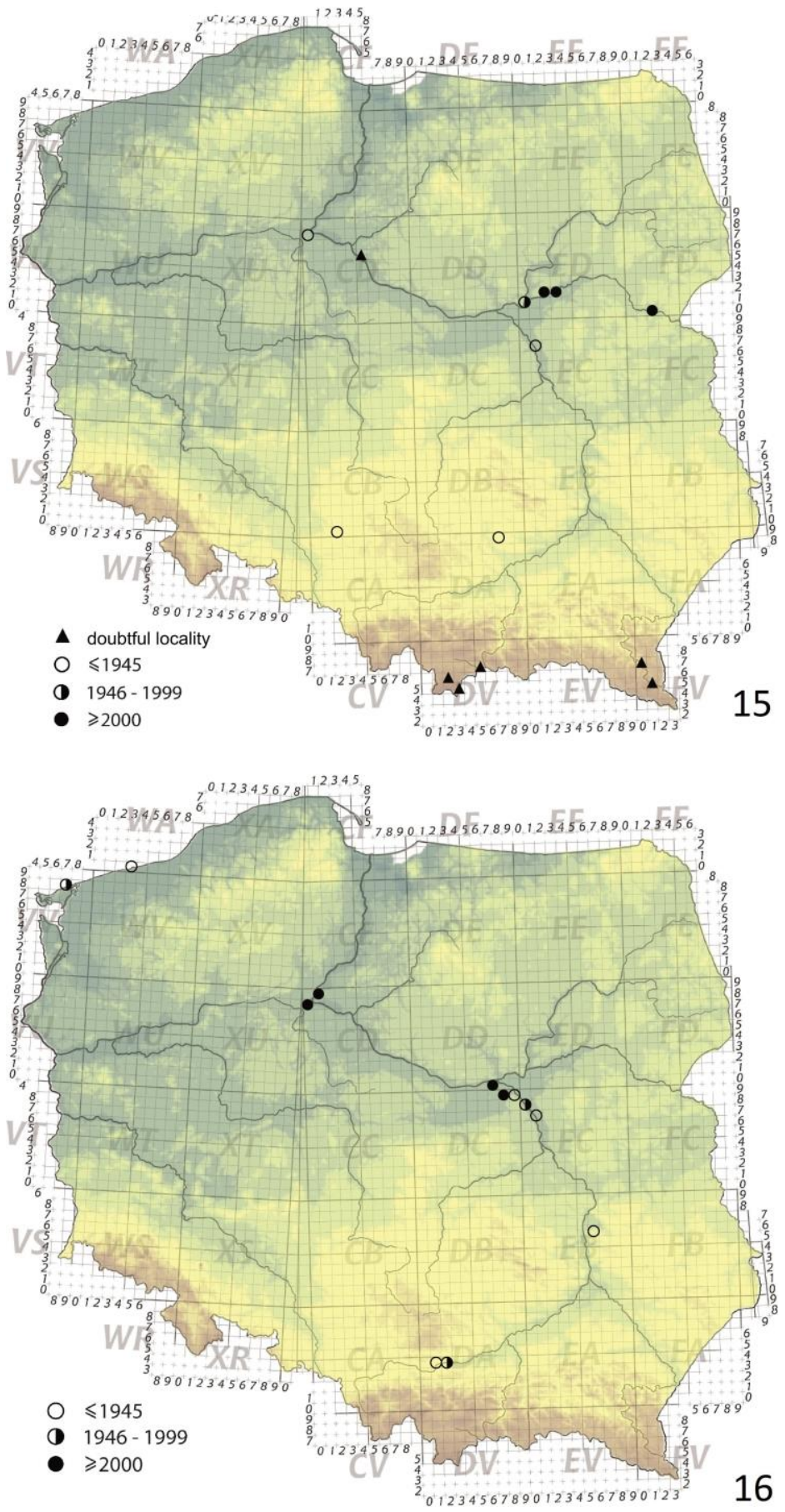

Figs 15, 16. Distribution maps: 15 - Psammoporus sabuleti, 16-Rhysothorax rufus. 


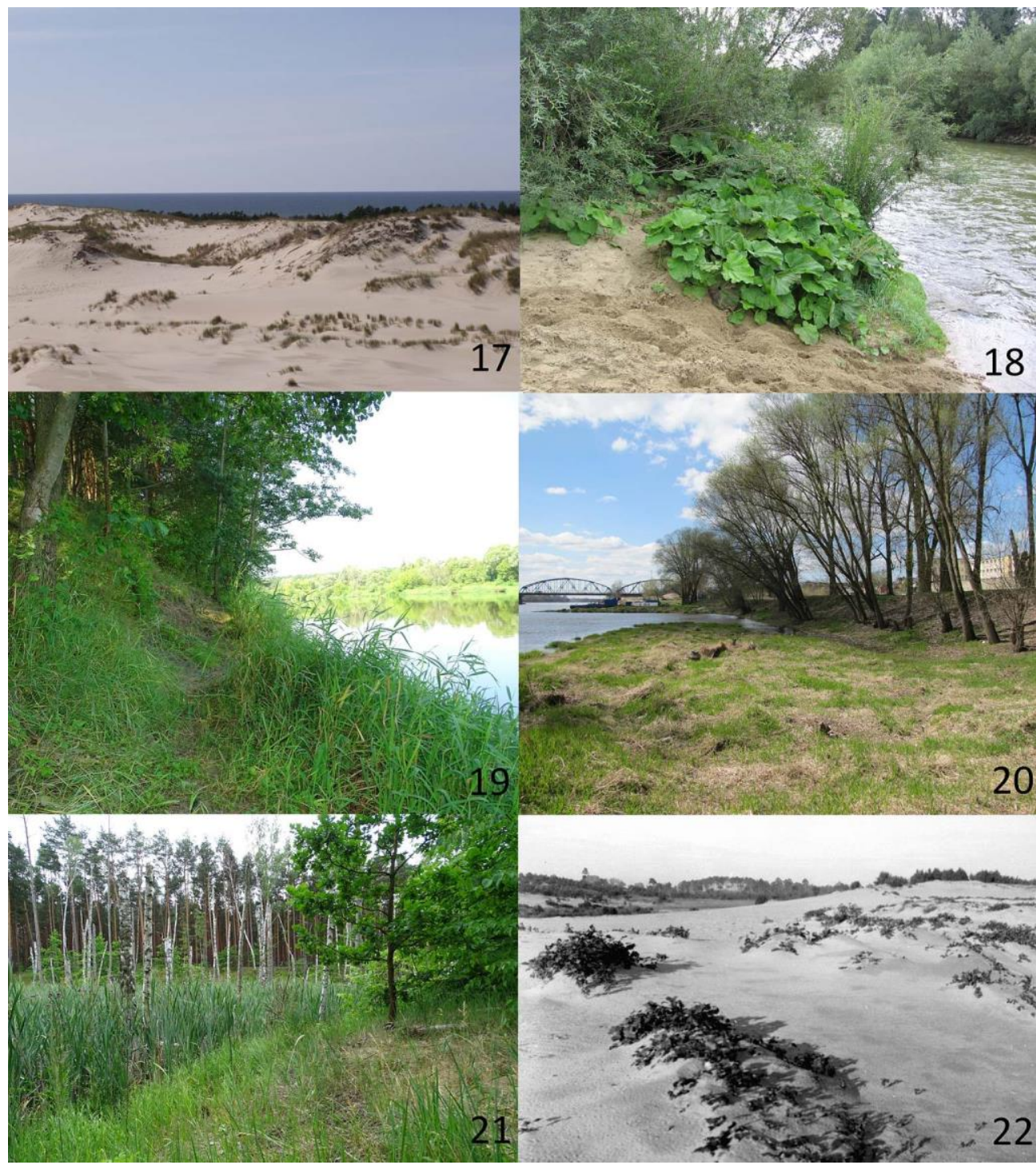

Figs 17-22. Typical habitat: 17 - Aegialia arenaria, Baltic Coast: vicinity of Smołdziński Las (Photo by Tomasz MoKrZYCKI), 18 - Psammoporus mimicus, Nowy Targ Basin: Ludźmierz (Photo by Łukasz MINKINA), 19 - P. sabuleti, Podlasie: Kózki (Photo by Adam BYK), 20 - Rhysothorax rufus, Wielkopolska-Kujawy Lowland: Bydgoszcz (Stary Fordon) (Photo by Bartłomiej PACUK), 21 - R. rufus, Mazovian Lowland: Kampinos National Park - vicinity of Palmiry (Photo by Adam BYK). 22 - Original appearance of the relict locality of $R$. rufus: Mazovian Lowland: eastern part of the Kampinos National Park (Photograph from the 1920s by Roman KoBENDZA; archives of the Kampinos National Park). 
XA47, XA57), on the beach, summer 1997, 2002, 2003; MARCZAK et al. (2006): Baltic Coast: Słowiński National Park, beach near Rowy (XA35), 28.VI.2005, 1 ex.; Słowiński National Park, beach in the vicinity of Czołpino (XA46), 2.VII.2005, 1 ex.; Słowiński National Park, beach in the vicinity of Smołdzino (XA46), 29.VI.2005, 2 exx.; WOLENDER\& ZYCH (2007): Baltic Coast: Świnoujście, recorded from the beach and coastal dunes, May - mid-September 2002, 2004, 2005 - single specimens (below 10 exx.), leg. M. Wolender, A. ZYCH; BYK (2012): Baltic Coast: Smołdziński Las ad Smołdzino (XA46), on the border between the beach and coastal dunes, 20.IX.2003, common, recorded by A. BYK, 6.VI.2009, common, recorded by T. MOKRZYCKI; Hel ad Władysławowo (CF55), on the beach, under decaying wood, 12.V.2004, 4 exx., leg. D. DOKTóR; Rąbka ad Łeba (XA67), on the beach, under decaying wood, 10.VII.2006, 3 exx., leg. D. DoKTóR; Krynica Morska ad Nowy Dwór Gdański (CF92), dead, on the border between the beach and coastal dunes, 6.VII.2010, 1 ex., obs. A. BYK.

\section{Comment on the literature data}

HILDT (1916) states that the records of A. arenaria from Zakopane, the vicinity of Busko and Ciechocinek are incorrect and should refer to Psammoporus sabuleti. He adds that Aegialia arenaria is an insect associated with coastal dunes in western Europe, and that the range of this species may extend as far as Gdańsk, in Pomerania. Based on HILDT's notes and a knowledge of the species' biology, the authors suspect that the information regarding A. arenaria from the vicinities of Olkusz and Ojców should also apply to Psammoporus sabuleti. Only one locality cited by HILDT in 1896 - Miłosna near Warszawa - may in our opinion be a historical one, because in those days all the circumstances connected with the occurrence of Aegialia arenaria were met. However, the presence of Psammoporus sabuleti in Zakopane in the Tatra Mts. still has to be corrected; this information should refer to $P$. mimicus.

\section{New data}

Baltic Coast: Vistula Spit, 4 exx., leg. J. KNIEPHOF, ex coll. P. FrAnCK [MIZ]; 2 exx., T. KNIEPHOF [USMB]; 1 ex., A. HOFFM. [USMB] [not included on the map, because there is no way of proving that the specimens come from the present-day territory of Poland]; Koszalin, 13 exx., leg. LÜtTwITZ, ex coll. StETTIN [MIZ]; Władysławowo, 3-6.VII.1937, 5 exx., leg. BARTOSZYŃSKI, ex coll. H. CISZKIEWICZ [MIZ]; Jastarnia, 14.VIII.1937, 1 ex., ex coll. MAKÓLSKI, ex coll. E. and G. MAZUR [MIZ]; Chałupy ad Puck, 18.IV.1959, 4 exx., leg. M. WĘGRZECKI [MIZ]; Krynica Morska ad Nowy Dwór Gdański (CF92), 23.VII17.VIII.1976, 2 exx., leg. M. MantiČ [JS]; 22.V.2015, 1 ex., leg. B. BuJniK [BB]; Władysławowo (CF37), 10-11.VI.1993, 4 exx., leg. R. Dobosz [RD]; Słowiński P. N. (XA46), 21.IX.1995, 1 ex., leg. S. KonWERSKI [SK]; Wisełka ad Międzyzdroje (VV78), 
1-15.VI.1998, 1 ex., leg. S. MAZUR [DFPE]; Mrzeżyno ad Trzebiatów (WV19), 1-7.VII.1998, 1 ex., 8-13.VII.1998, 4 exx., leg. S. KonwERSKI [SK]; Łazy ad Koszalin (WA71), 8-20.VIII.1999, 1 ex., 18-28.VIII.2001, 1 ex., 29.III - 3.IV.2003, 3 exx., leg. S. Konwerski [SK]; Czołpino ad Smołdzino (XA46), 23.VIII.2003, 1 ex., leg. T. GAZUREK [TG]; Ustronie Morskie ad Kołobrzeg (WA40), 10-17.VII.2004, common, obs. T. GaZUREK; Rowy ad Ustka (XA35), 2.V.2009, 1 ex., leg. B. PACUK [BP]; Bobolin ad Dąbki (WA82), 10-20.VII.2006, 1 ex., leg. S. KONWERSKI [SK]; Karwieńskie Błoto Drugie (CF17), 1-3.V.2011, leg. A. MATUSIAK [ŁM]; Sarbinowo (WA61), 3-13.VII.2012, 5 exx., leg. J. MAZEPa [ŁM]; Sarbinowo (WA61), 4-13.VII.2012, 7 exx., leg. J. MAZEPA [CN]; Dębki ad Krokowa (CF18), 16.V.2015, 31 exx., leg. D. RogowsKi [30 exx. AB; 1 ex. ŁM]; 22.V.2015, 51 exx., leg. S. MagnusZewska, B. PYŚniaK [50 exx. AB; 1 ex. CN]; Frombork ad Braniewo (DF12), 20.V.2015, 7 exx., leg. M. BYK, S. BYK, P. SEMKIW [MB]; Kadyny ad Frombork (DF01), 20.V.2015, 2 exx., leg. M. BYK, S. BYK, P. SEMKIW [MB]; Karwia ad Władysławowo [CF27], 22.V.2015, 15 exx., leg. D. RogOwSKI [AB]; Chałupy ad Władysławowo (CF37), 23.V.2015, 5 exx., leg. S. MAGNUSZEWSKA, B. PYŚNIAK, D. Rogowski [AB]; Ustka ad Słupsk (XA15), 5.VI.2015, 5 exx., leg. R. CieŚlaK [RC]; Jastarnia ad Władysławowo (CF46), 5-6.VI.2015, 25 exx., leg. M. KAŹMIERCZAK [MK]; Pogorzelica ad Rewal (WV09), 24.IV.2016, common, obs. P. SZABŁOWSKI, K. STASZCZYK [AB]; Chłopy ad Mielno [WA61], 3.V.2016, 1 ex., leg. D. MarschaŁKOWSKa [AB]; Sarbinowo ad Mielno (WA61), 3.V.2016, 2 exx., leg. D. MARSCHA£KOWSKA, K. SOBAJTIS [AB]; Gąski ad Mielno (WA51), 3.V.2016, 1 ex., leg. D. MARSCHAŁKOWSKA, K. SOBAJTIS [AB]; Wieniotowo ad Ustronie Morskie (WA50), 3.V.2016, 2 exx., leg. D. MARSCHALKOWSKA, K. SOBAJTIS [AB].

Mazovian Lowland: near Świder, 25.VII.1906, 1 ex., MĄCZYŃSKI [USMB]; Łomna ad Łomianki (DD80), 21.VI.2014, 1 ex., leg. D. MARCZAK [AB].

\section{Psammoporus mimicus PITTINO, 2006}

(Figs 2, 6, 10, 14, 18)

\section{Supplementary description}

Aedeagus: elongate; parameres distinctly shorter than phallobase, in lateral view directed parallel to base, acute apex. Epipharynx: very distinctly transverse, rounded at sides, with anterior margin of pedia gently convex; corypha small, more or less distinctly visible, slightly produced to very small, barely noticeable, very slightly produced; chaetopariae long, not very dense, visible at magnifications greater than 50x, occurs singly (if present at all); rather short and usually rather thick chaetopediae; tormae long, slender. 


\section{Comment}

Stenotope, psammobiont. Local, rather rare, but sometimes locally abundant. Rather widely distributed in central Europe, in mountain and foothill areas. Collected mainly on sandy riverbanks, under stones. Observed from March to August. Two generations per year; the imago is the overwintering stage; preimaginal stages unknown.

\section{New observations}

In Poland the species can be collected from April to the first frosts (usually in September, rarely October). After that time these beetles burrow deep into the ground, so it is not easy to collect them then. Very probably, they move a short distance upriver. Specimens were collected on the banks of mountain rivers, along both fast-flowing streams and slow-flowing rivers, but only in the sluggish parts of rivers were they found in larger numbers. In nearby fast-flowing streams, these beetles were found in the roots of grass very near to the riverbank; on slow-flowing sections, they were collected in sandy places (they avoided stony and gravelly ground). The distance from the riverbank where the specimens were caught differed, depending on the character of the riverbank. When the riverbank was steep, the beetles were mainly collected slightly above (about $0.5-1 \mathrm{~m}$ ) the highest water level after winter, but relatively near to the water (about 1-2 m). Along flat riverbanks with large adjacent areas of intermittently flooded land, specimens were frequently collected at some distance (up to $8 \mathrm{~m}$ ) away from the water. This species, like the previous one, certainly has two generations per year. In places with slow-flowing water Psammoporus was collected mainly in the roots of willow (Salix L.) (in the living roots, with mycorrhizae). We cannot exclude the possibility that the species may occasionally be mycophilous. As in P. sabuleti, there is a noticeable gap between populations (usually in July), and the imago takes one or two weeks to attain its full colouring. In addition, L3 larvae were collected in the gap between the two populations (a description of them is in preparation).

\section{Literature data}

PITTINO (2006): Upper Silesia: Teschen W. Prock, 1 ex. [NMV].

\section{Comment on the literature data}

Based on our knowledge of the species, the following data relating to Psammoporus sabuleti should apply to Psammoporus mimicus: ŁOMNICKI (1874): Nowy Targ Basin: Zakopane, Tatra Mts., 30.VI; STEBNICKA (1977): Pieniny Mts.: Krościenko, 1.VIII.1924, coll. Tenenbaum [ZIP], Czorsztyn, 17.VI.1972, Z. Stebnicka [ISEA], Sromowce, 26.VI.1973, Z. STEBNICKA [ISEA]; Nowy Targ Basin: Zakopane, 1.VII.1910, M. RYBIŃSKI [ISEA]; Tatra Mts.: Roztoka, 2, 6.VI.1976, M. GaŁUSzKa [ISEA]; Bieszczady Mts.: 
Solina, 18.VII.1971, Z. STEBNICKA [ISEA]. According to BUNALSKI (2000): Bieszczady Mts.: Wetlina (FV15), 7.VI.1986, 1 ex., leg. T. MAJEWSKI, under a stone on the bank of a stream - this specimen is definitely P. mimicus; Marek BUNALSKI confirmed its identity and passed this information on to us. Finally, today we have to treat Zakopane as a historical locality, because the vast majority of the river banks are regulated there, which precludes the existence of this species.

\section{New data}

Western Beskid Mts.: Cieszyn, 1 ex., Th. v. Wanka, ex coll. Sz. Tenenbaum [MIZ] [not included on the map, because there is no way of proving that specimens come from the present-day territory of Poland]. Tatra Mts.: 1 ex., coll. MAZUR, ex coll. E and G. MAZUR [MIZ] [not included on the map, because there is no way of proving that the specimens come from the present-day territory of Poland]; Nowy Targ Basin: Ludźmierz (DV27), 3.VIII.2014, 2 exx., 11.VIII.2014, 5 exx., 17.VIII.2014, 1 ex., 25.IV.2015, 1 ex., 14.VI.2015, 1 ex., 7.VIII.2015, 21 exx., 29.VIII.2015, 1 ex., 6.IX.2015, 1 ex., 19.IX.2015, 1 ex., leg. Ł. Minkina [ŁM]; 3.VIII.2014, 5 exx., 30.VII.2016, 13 exx., leg. C. NOWAK [CN]; Nowy Targ (DV28), 10.V.2015, 2 exx., leg. Ł. Minkina [ŁM]; 30.VII.2016, 2 exx., leg. C. NowaK [CN]; Klikuszowa (DV28), 16.V.2015, 1 ex., leg. Ł. Minkina [CN]; Obidowa (DV28), 16.V.2015, 1 ex., leg. Ł. MinKINA [ŁM]; Czarny Dunajec (DV17), 5.VI.2015, 1 ex., leg. Ł. MINKINA [CN]; Łopuszna (DV38), 5.VIII.2015, 1 ex., leg. Ł. MinkINA [ŁM]; Dębno (DV47), 6.VIII.2015, 1 ex., leg. Ł. MinkINA [ŁM]; Bieszczady Mts.: Ustrzyki Górne (FV23), 1.V.2017, 1 ex., leg. T. GAZUREK [TG].

\section{Psammoporus sabuleti (PANZER, 1797)}

(Figs 3, 7, 11, 15, 19)

\section{Supplementary description}

Aedeagus: elongate; parameres distinctly shorter than phallobase, in lateral view with acute apex protruding at an acute angle from base. Epipharynx: very distinctly transverse, rounded at sides, with anterior margin of pedia slightly convex; corypha small, not produced to very slightly produced beyond the anterior margin of the epipharynx; chaetopariae long, not very dense, visible at magnifications greater than 50x, occurs singly (if present at all); rather short, usually rather thick chaetopediae; tormae long, slender.

\section{Comment}

Stenotope, psammobiont. Local, rare, but locally sometimes quite abundant. Rather widespread in northern and central European lowlands. Collected mainly on sandy 
riverbanks, under stones, in or under decaying wood, and roots. Recorded from March to August. Two generations per year; the imago overwinters; preimaginal stages unknown.

\section{New observations}

This species was found mainly among the roots of trees, chiefly willow (Salix L.) and alder (Alnus MILL.). It appears to prefer steepish slopes, very probably because in environments like this, it is easier to move up or down if the water level changes after winter. The species is almost certainly bivoltine. There is a perceptible gap between the generations, varying in length from year to year. At the beginning of July the number of specimens decreases rapidly, but in mid-July most of the specimens observed are reddishbrown. Interestingly, the imago requires about one to two weeks to attain its final colouration. This may suggest that these insects spend most of their lives underground (this species was never observed on the surface of the earth during the day, even when it was very cloudy, or when it rained), as a result of which acquiring the final colouration is delayed. In our opinion, the specimens collected under stones and in or under decaying wood were collected here accidentally; many specimens may have been washed away by floodwaters.

\section{Literature data}

ŁOMNICKI (1874): Nowy Targ Basin: Zakopane, Tatra Mts., 30.VI; HILDT (1916): Mazovian Lowland: at the confluence of the River Świder with the River Wisła (Vistula) during a flood, 7.VII.1901, a few specimens, leg. W. MĄCZYŃSKI; Małopolska Upland: vicinity of Busko [Zdrój]; Wielkopolska-Kujawy Lowland: vicinity of Ciechocinek; StebnicKa (1977): Pieniny Mts.: Krościenko, 1.VIII.1924, coll. Tenenbaum [ZIP], Czorsztyn, 17.VI.1972, Z. Stebnicka [ISEA], Sromowce, 26.VI.1973, Z. StebnicKA [ISEA]; Nowy Targ Basin: Zakopane, 1.VII.1910, M. RYBIŃSKI [ISEA]; Tatra Mts.: Roztoka, 2, 6.VI.1976, M. GAŁUSZKA [ISEA]; Bieszczady Mts.: Solina, 18.VII.1971, Z. STEBNICKA [ISEA]; BUNALSKI (2000): Mazovian Lowland: Zegrze [district of Pułtusk] (ED01), 1.V.1948, 1 ex., leg. R. BIELAWSKI, after the spring snowmelt; Bieszczady Mts.: Wetlina (FV15), 7.VI.1986, 1 ex., leg. T. MAJEWSKI, under a stone on the bank of a stream; PITTINO (2006): Wielkopolska-Kujawy Lowland: Bromberg (=Bydgoszcz) 1 ex. [NMV].

\section{Comment on the literature data}

ŁOMNICKI first supplied information on $P$. sabuleti from Zakopane, in the Tatra Mts. in 1874. In 1876 he stated that he had earlier made it known that there were 2 specimens deposited in the Dzieduszycki Museum in Lviv. Most probably, based on that information, HILDT (1896) published the information about Aegalia arenaria in Zakopane; he subsequently explained that this data should apply to Psammoporus sabuleti (HILDT 1916). 
However, according to today's knowledge, that information probably refers to P. mimicus. In 1896 HILDT stated that Aegalia arenaria had been reported from the Kraków-Wielun Upland (vicinity of Olkusz, and Ojców). Based on his next manuscript, and our knowledge of A. arenaria, we suspect that this information relates to Psammoporus sabuleti. In our opinion, based on our knowledge about the biology of Psammoporus species THOMSON, 1863, all the data cited by STEBNICKA in 1977 should refer to $P$. mimicus. The information from BUNALSKI (2000) about $P$. sabuleti from Wetlina also applies to $P$. mimicus.

\section{New data}

Mazovian Lowland: Świder, 11.VII.1903, 2 exx., ex coll. MĄCZYŃSKI [USMB], Zegrze ad Legionowo, 14.V.1939, 1 ex., leg. MAKÓLSKI, ex coll. H. CISZKIEWICZ [MIZ], Zegrze ad Legionowo, 18.VI.1939, 6 exx., ex coll. H. CISZKIEWICZ [MIZ], Deskurów ad Wyszków (ED22), 17-27.VI.2001, 4 exx., 11-13.VI.2004, 2 exx., leg. A. MATUSiAK [AM, AB, LM], Zastruże ad Wyszków (ED32), 4.VI.2015, 1 ex., 8.VIII.2015, 2 exx., 19.IX.2015, 1 ex., leg. P. RYCHLICKI [DFPE, AB]. Podlasie: Kózki ad Siemiatycze (FD20), 21.V.2004, 12 exx., leg. L. KoloniČnÝ, J. StANOvSKÝ, K. ORSZUliK [LK, JS, KO]; 15.VII.2012, 15 exx., leg. C. NowaK [13 exx. CN; 2 exx. ŁM]; 20.VII.2013, 4 exx., leg. Ł. MinKINA [ŁM]; 20.VII.2013, 3 exx., leg. C. NowaK [CN]; 20.VII.2013, 1 ex., leg. M. BIDAS [AB]; 11.VII.2014, 33 exx., 19.VI.2016, 3 exx., leg. A. BYK [AB]; 12.VII.2014, 6 exx., leg. Ł. Minkina [ŁM]; 12.VII.2014, 29 exx., leg. C. NowaK [CN]; 14.VII.2014, 20 exx., leg. R. PIASKOWSKI [AB, RP]; 13.VI.2015, 1 ex., 18-19.VI.2016, 11 exx., leg. R. CIEŚLAK [RC]; 26.V.2016, 1 ex., leg. C. NowAK [CN]. Upper Silesia: Zawadzkie, 31.VII.1939, 1 ex., H. NOWOTNY [USMB].

\section{Rhysothorax rufus (FABRICIUS, 1792)}

(Figs 4, 8, 12, 16, 20-22)

\section{Supplementary description}

Aedeagus: elongate; parameres slightly shorter than phallobase, with very distinctly downward-pointing, blunt apex. Epipharynx: very distinctly transverse, rounded at sides, with anterior margin of pedia gently convex; without typical corypha, with six very widely spaced appendages; chaetopariae very long and dense, distinctly distinguishable from single, rather short chaetopediae; tormae moderately long, slender.

\section{Comment}

Stenotope, psammobiont, halotolerant. A very rare Holarctic species. Distribution from Great Britain to western Kazakhstan. Most probably introduced to the USA and Canada 
from Europe. Usually found as single specimens. Collected mainly on sandy dunes near large rivers, less frequently on sea/ocean coasts, on shores of small lakes near large rivers or sea coast, and on sandy beaches of islands. Rarely in other environments, but almost always with sandy soil (even if covered with a layer of mulch); it is almost always the case that there is a river or some other body of water from among those mentioned above near the locality of occurrence. Imagines are most likely buried in the sand most of the time. This species flies in the evenings and at night. In the Netherlands it was collected in a nest of Formica rufa (L.). Frequently found in washed up plant debris and other dead plant matter. In Ukraine, found under a dead fish. In continental Europe only once found in larger numbers - on sandy dunes near Liepāja (Latvia). In England, it was frequently found in the Wallasey Sandhills in 1885 and 1886. In England it appeared to be restricted to the area between the Rivers Dee and Ribble, on the sand dunes at Southport, Birkdale and Wallasey until 1906, where it was abundant.

Observed from January to September. The imago overwinters; preimaginal stages unknown.

\section{New observations}

Despite targeted searches, the authors failed to find any specimens in sand. One specimen was found dead. Analysis of existing data yields equivocal results, hence the continued research into this species. There is clearly a need to unambiguously determine the typical living habitat and biology of this species in Poland. Based on flight times and other circumstances of collection, we conclude that the flight of this species is connected more with humidity and high air temperatures than with time of day; earlier authors had suggested that this species flies in the afternoons and evenings.

\section{Literature data}

HILDT (1896): Mazovian Lowland: during a rise in the water level in the River Wisła (Vistula), in foam, near Żerań close to Warszawa, 20.VI.1894, 1 ex., leg. L.F. HILDT, Bielany, in a decaying oak stump, leg. E. SzLEZYGIER; STEBNICKA (1977): Mazovian Lowland: Warszawa: Świder, 16.VII.1906, W. MĄCZYŃSKI [MIZ], Warszawa: Gocław, 12.I.1948, on the bank of the River Wisła, R. BIELAWSKI [MIZ], Warszawa: Gocław, 27.II.1950, M. MrocZKowsKi [MIZ], Kraków-Wieluń Upland: Kraków: 29.IV.1939, S. POPEK [ISEA], Kraków: 30.VII.1973, under vegetation near the River Wisła, Z. STEBNICKA [ISEA]; BURAKOWSKI et al. (1983): Małopolska Upland: Kraków-Zwierzyniec (STEBNICKA, oral report); BUNALSKI (2000): Baltic Coast: Woliński National Park, Wisełka (VV78), 2.VII.1991, 1 ex., leg. A. MELKE, on the shore of a small lake; MARCZAK et al. (2012): Mazovian Lowland: Truskaw (DC89), 27.V.2010, 1 ex., on sand in an area of scrub, leg. D. MARCZAK. 


\section{Comment on literature data}

The locality given by MARCZAK et al. (2012) requires correcting. The actual locality is: Mazovian Lowland: the Sieraków strict nature reserve (DC89), 27 V 2010, 1 ex., when beating vegetation growing along paths with a sweep net, leg. D. MARCZAK. The error resulted from the malfunctioning of the program handling the database. By way of additional information, the specimen was collected between 11:00 and 14:00 hrs, on the edge of an alder swamp forest and mixed coniferous forest.

\section{New data}

Baltic Coast: Kołobrzeg, 1 ex., ex coll. P. FRANCK [MIZ]. Kraków-Wieluń Upland: Kraków, 1 ex., near the River Wisła, after a flood, leg. Dr. MAZUR, ex coll. E. et G. MAZUR [MIZ]. Lublin Upland: Opole Lubelskie (Trzy Słupki), 26.V.1915, 1 ex., ex coll. W. EICHLER [MIZ]. Wielkopolska-Kujawy Lowland: Bydgoszcz-Stary Fordon (CD19), "Solecka Dolina Wisły" Natura 2000 area, 12.VI.2014, 1 ex., (dead), on a slope about $20 \mathrm{~m}$ from the Wisła riverbank, leg. B. PACUK [BP], Otorowo near Bydgoszcz (CD08), 29.V 11.VI.2016, 2 exx., "Solecka Dolina Wisły" Natura 2000 area, in a ground trap under an old willow tree on the Wisła riverbank, on periodically inundated land between flood embankments, leg. T. RUTKOwSKI [TR]. Mazovian Lowland: Palmiry ad Czosnów ad Nowy Dwór Mazowiecki (DC89), on a car bonnet, around 16:00 hrs, 14.VI.2015, 1 ex., leg. D. MARCZAK $[\mathrm{AB}]$; the car was parked in that locality between 14:00 and 16:00 hrs, the air was very humid, and the specimen was found about half an hour before a severe thunderstorm broke; Łomna ad Czosnów ad Nowy Dwór Mazowiecki (DD80) near a large sand dune, a live specimen, carried by the Wisła river current, a hot day, around 18:00 hrs, 31.V.2018, 1 ex., leg. A. MATUSiaK, A. BYK [AM].

\section{General comments and a key to the identification of the Aegialiinae of Poland}

Based on the morphology of the external characters and aedeagus, STEBNICKA (2011) demonstrated that the genus Rhysothorax BEDEL, 1911 has an evolutionarily indirect status between Aegialia LATREILLE, 1807 and Psammoporus. The structure of the epipharynx appears to support this hypothesis. In addition, the modified corypha, in our opinion, indicates that Rhysothorax rufus utilizes different food sources from the other species. The differences between the epipharynx in Psammoporus sabuleti and P. mimicus seem to us to be barely perceptible (the corypha in P. mimicus is usually slightly less well developed but we suspect that this difference is statistically insignificant). Although the differences in the aedeagus structures are minimal, they clearly confirm the separateness of these species. As the aedeagus in Aegialiinae is rather soft, delicate and easily deformed, their analysis by 
inexperienced researchers, or of the genitalia of old specimens, may lead to ambiguous results.

Based on PITTINO's (2006) key to the European Psammoporus, inexperienced researchers may have problems identifying the species that can be found in Poland. The diagnostic features suggested by PITTINo, like the structure of the tenth interval, the shape of the protibiae and the sides of the pronotum, are easily visible when we have plenty of specimens in good condition, but they are rather difficult to pinpoint as they often overlap slightly. In view of this, we have compiled the following identification key for Polish Aegialiinae.

1. Metatibiae thick, distinctly extended at apex. Apical spurs of metatibiae leaf-shaped, rounded at apex. Metatarsomeres thick, short, rather wider than longer. Claws more or less reduced, rather short, poorly arcuate. Punctures in elytral striae hardly visible, not intending margins of intervals. Punctation of pronotum very fine, barely visible. Punctation near base of head of the same size, or larger than that at base of pronotum. Apex of aedeagus blunt, or with short, acute apex. 2.

- Metatibiae slender, not distinctly extended at apex. Apical spurs of metatibiae normally developed, acute at apex. Metatarsomeres rather slender, elongate, rather longer than wide. Claws rather small, but clearly arcuate. Punctures in elytral striae very distinct, very distinctly intending margins of intervals. Punctation of pronotum coarse, very clearly visible. Punctation near base of head smaller than that of pronotal disc. Apex of aedeagus with elongate, acute apex.

2. Body stocky, ovate. Structure of pronotum smooth. Base of pronotum not bordered. Elytral striae narrow, poorly marked. Elytral intervals nearly flat. Transverse carinae of meso- and metatibiae distinctly developed. Punctation near base of head the same size as punctures of pronotal disc. Colour usually dark brownish to blackish. Aedeagus stocky, acute at apex. Epipharynx with small but distinct corypha, sides of anterior border excavate, short and thick tormae. Aegialia arenaria (FABRICIUS, 1787)

- Body slender, elongate. Structure of pronotum wrinkled. Base of pronotum thinly, but distinctly bordered. Elytral striae wide, very deep. Elytral intervals more or less convex. Transverse carinae of meso- and metatibiae poorly developed. Punctures near base of head distinctly larger (about 7-15 times) than punctures of pronotal disc. Colour usually red-brown. Aedeagus slender, with blunt apex. Epipharynx without typical corypha, but with six widely distributed appendages, sides of anterior border not excavate, moderately long, slender tormae. .......................... Rhysothorax rufus (FABRICIUS, 1792)

3. Base of pronotum before hind angles truncate to (rather infrequently) slightly sinuate, always with regular curvature. Parameres, in lateral view, with apex at right angles to phallobase. Psammoporus mimicus PITTINO, 2006 
- Base of pronotum before hind angles more or less distinctly sinuate, sinuation at least basally with distinct, nearly rectangular cut-off point. Parameres, in lateral view, with apex at an obtuse angle to phallobase. Psammoporus sabuleti (PANZER, 1797)

Hitherto, both Psammoporus species were known from a rather small number of specimens: most were collected incidentally, so the distribution of these species in Poland was (and still is) incompletely known. This study has provided an opportunity to learn more about their current ranges of distribution. The biology of Psammoporus and Aegialia species seems to be well enough known to enable further research to be carried out. What remains problematic is the biology of Rhysothorax rufus: this is still enigmatic. Because its biology is not well known, it is not easy to collect larger numbers of this species, or to make effective plans for trapping it, so further research is necessary in this respect. Our study has shown that Aegialiinae are obligate stenobionts, incapable of living outside an appropriate habitat. Even small changes to their habitats - especially riverbeds, and to a slightly lesser extent sand dunes - lead to significant reductions in their numbers or even their local extinction. A good example is Psammoporus mimicus: this species has never been found where a riverbed has been regulated. Moreover, P. mimicus seems to be sensitive to such forms of regulation as the construction of reservoirs like Lake Czorsztyńskie; we have never collected it in this area. Because of this, we consider that the sites where Aegialiinae do occur (especially inland) deserve protection.

The Kampinos National Park deserves special attention. Towards the end of the Ice Age, aeolian processes taking place on and around oxbow lakes, of the River Wisła (Vistula) created dunes reaching up to $30 \mathrm{~m}$ in relative height. About 12,500 years ago, the dunes were colonized by vegetation and thus preserved; today they have an area of nearly 20,000 ha, the largest such natural formation known in Europe. Initially, swamps covered the former Wisła riverbed. Organic matter accumulated in stagnant water bodies, and the process of swamping took place. Fertile and moist soil was overgrown by rushes and swamp vegetation. Peat deposits began to form from their dead debris, which led to the formation of fens, which occupy parts of the park and maintain the humidity, this governing the area's climate. In later periods, some of them were taken over by woodland vegetation (alder and birch), and finally mixed coniferous forest; the rest of the dunes remained open. The primary natural relations have only been disrupted by man over the last two centuries, by draining and infilling part of the swamps, thereby turning them into meadows and pastures. The environment created in this way fixes the factors necessary for the occurrence of Rhysothorax rufus, i.e. layers of river sand in the ground, and a watercourse nearby. Considering that $R$. rufus has already been recorded in similar inland sites (for example, in Germany), and the natural history of the Kampinos National Park, we conclude that this 
species is still here over a large area as a relict. This further emphasizes the uniqueness of this National Park.

\section{ACKNOWLEDGEMENTS}

For sharing their data and making their collections available for our study, the authors are grateful to Jiři STANOVSKÝ, Lubomir KolONIČNÝ, Kamil ORSZULIK (Czech Republic), Bartłomiej BUJNIK, Marek BYK, Rafał CIEŚLAK, Roland DOBOsZ, Maciej KAŹMIERCZAK, Rafał PIASKOwSKI and Tomasz GAZUREK (Poland). Special thanks go to Marcin KACZMARCZYK and Michał STANIASZEK for their help in the preparation of maps. Cordial thanks go to Darren J. MANN for providing us with some of the literature.

\section{REFERENCES}

AleKSANDRowicz O., MARCZAK D., PoBiedZiŃSKi A., KAPUŚciŃSKI H. 2004. Summer occurence of scarab beetles (Coleoptera, Scarabaeidae) of the Słowiński National Park. Parki Narodowe i Rezerwaty Przyrody, 23 (3): 504-511. (in Polish)

BunALSKi M. (1999) 2000. New localities of two rare species of the genus Aegialia LATREILLE, 1807 (Coleoptera: Scarabaeoidea). Wiadomości Entomologiczne, 18 (4): 252. (in Polish)

Burakowski B., Mroczkowski M., Stefańska J. 1983. Scarabaeoidea, Dascilloidea, Byrrhoidea i Parnoidea. Beetles - Coleoptera. Katalog Fauny Polski. XXIII, 9. Państwowe Wydawnictwo Naukowe, Warszawa. (in Polish)

BYK A. 2012. New Polish records of some beetle species from the family Scarabaeidae (Coleoptera). Wiadomości Entomologiczne, 31 (2): 121-123. (in Polish)

CYKOwsKi R.K. 1979a. Research on insect fauna of dune biotopes of the Słowiński National Park. Chrońmy Przyrodę Ojczystą, 35 (6): 20-23. (in Polish)

CYкоWSKI R.K. 1979b. Beetles (Coleoptera) of the coastal strip of gray dunes in the Słowiński National Park. Biuletyn Informacyjny Polskiego Towarzystwa Entomologicznego, 22: 29-34. (in Polish)

Dellacasa G., Dellacasa M., Mann D.J. 2010. The morphology of the labrum (epipharynx, ikrioma and aboral surface) of adult Aphodiini, and its implications for systematics. Insecta Mundi, 132: 1-21.

Dommer A. 1850. Nachtrag zu dem Verzeichniss der Käfer Preussens. Von Prof E. v. SiEBOLD. Neue Preußische Provinzial-Blätter, 9: 199-214, 276-283.

HiLdT L.F. 1896. Domestic scarab beetles or dung beetles. Pamiętnik Fizyograficzny, 14 (3): 153228. (in Polish)

HiLDT L.F. 1916. Additions to the description od "Domestic scarab beetles or dung beetles". Pamiętnik Fizyograficzny, 23 (2): 133-139. (in Polish) 
ILLIGER K. 1798. Verzeichniss der Käfer Preussens. Entworfen von Johan Gottlieb KugELANN Apotheker in Osterode. Mit einer Vorrede des Professor und Pagenhofmeisters Hellwig in Braunschweig, und dem angehängten Versuche einer natürlichen Ordnungs- und Gattungs-Folge der Insekten Halle. J.J.Gebauer, Halle.

ŁoMNICKI M.A. 1874. Additional list of Galician beetles. Sprawozdanie Komisyi Fizyjograficznej, 8: 12-18. (in Polish)

Łomnicki M.A. 1913. List of beetles (Coleoptera) of Polish territories. Kosmos, 38: 21-155. (in Polish)

Marczak D., Hoste-DanyŁow A., PepŁowska-Marczak D., Melke A., Pacuk B., Masiarz J. 2012. New records of rare, interesting and protected beetle species (Coleoptera) of Kampinos National Park's fauna. Parki Narodowe i Rezerwaty Przyrody, 31 (1): 109-119. (in Polish)

MArCZAK D., KomosińSKi K., PoBiedZiŃSKi A. 2006. Halophilous beetles (Insecta: Coleoptera) from Słowiński National Park. Wiadomości Entomologiczne, 25 (Supl. 2): 155-158. (in Polish)

PitTino R. 2006. A revision of the genus Psammoporus Thomson, 1859 in Europe, with description of two new species (Coleoptera Scarabaeoidea: Aegialiidae). Giornale Italiano di Entomologia, 11: $325-342$.

RÖSSNER E. 2012. Die Hirschkäfer und Blatthornkäfer Ostdeutschlands (Coleoptera: Scarabaeoidea). Verein der Freunde und Förderer des Naturkundemuseums Erfurt e.V., Erfurt.

SHARP W. E. 1908. The Coleoptera of Lancashire \& Cheshire. Gibbs \& Bamforth, Market Place.

STEBNICKA Z. 1976. Grupa podrodzin Scarabaeidae laparosticti. Żukowate-Scarabaeidae. Klucze do oznaczania owadów Polski. XIX, 28a. Państwowe Wydawnictwo Naukowe, Warszawa. (in Polish)

StebnickA Z. 1977. A Revision of the World Species of the Tribe Aegialiini (Coleoptera, Scarabaeidae, Aphodiinae). Acta Zoologica Cracoviensia, 22 (11): 397-505.

STEBnicKa Z. 2011. Aegialiini and Eremazini of the World. Iconography. Institute of Systematics and Evolution of Animals Polish Academy of Sciences, Kraków.

WOLENDER M., ZYCH A. 2007. Beetles (Coleoptera) from seaside beach and dunes in the regions of Świnoujście, Międzyzdroje and Wisełka (Poland) located along the southern coast of the Baltic Sea. Baltic Journal of Coleopterology, 7 (1): 61-71.

Received: 7 September 2018

Accepted: 3 October 2018 